\title{
ORIENTATION IN TIME AND SPACE - FROM KNOWLEDGE TO COMPETENCE
}

DOI: https://doi.org/10.18509/GBP210625m

UDC: $37.043: 911(497.2)$

UDC: $37.015 .31: 57.081 .11(497.2)$

\author{
Stanislava Misheva \\ Sofia University "St. Kliment Ohridski”, Faculty of Geology and Geography, Department \\ "Regional development", Bulgaria
}

\begin{abstract}
The localization of geographical objects on the earth's surface is a key skill formed in the geography education. It is a basic geographical skill and the first step in the development of students' geographical literacy. In the context of the geography didactics and teaching methodology, the question of acquiring this skill has a specific significance. The notions in the society about geography and geographical science are well-known, connecting it above all with its localization character. This, in a sense, depersonalizes geography, making it a source of simple illustrative, classifying, static, and "slow" knowledge.

It is a fact that the localization of objects in space is the essential basis on which geographical knowledge develops. It is also a fact that it is the basis of all geographical methods of research, regardless of whether they are rationalistic or humanistic, whether they are oriented to spatial analysis or to the study of the development of processes and phenomena in space. Too often, the localization of objects and phenomena in space is considered a basic prerequisite for the formation of "true geographical knowledge", even defined as a key goal of teaching geography in high school. The problem is not so much in the dissemination of this opinion among society as in its perception by a number of geography teachers. This is related to the misconception and vision of geography, to the underestimation of its educational potential, to its reduction to an ordinary subject, whose trivial task is to indicate where and how large are the natural and anthropogenic objects on the earth's surface.

With this report, we are focusing on this very issue. We try to read the "misunderstandings" by outlining the main geodidactic possibilities for this.
\end{abstract}

Keywords: geographical knowledge, geographical skills, localization in space, geographical competence

\section{INTRODUCTION}

The localization of geographical objects on the earth's surface is a key skill formed in the process of learning geography. [11] It is a basic geographical skill and the first step in the development of students' geographical literacy. [1], [2] In the context of the didactics of geography and teaching methodology, the question of acquiring this skill has a specific significance. The notions in the society about geography and geographical science are well-known, connecting it above all with its localization character. This, in a sense, depersonalizes geography, making it a source of simple illustrative, classifying, static, and "slow" knowledge. In this line of thought, the knowledge of finding geographical objects is the essential basis of geographical knowledge, on which all other reflections based on spatial analysis or study of territorial processes are based. [9] 
Today, the acquisition of this knowledge is considered a major goal in the teaching of geography in high school. This misconception is common among teachers whose teaching process does not offer innovative and alternative methods of teaching the discipline. For this reason, geography is all too often seen as an ordinary school subject, which aims only to teach where certain objects are located and what their physical characteristics are. According to A. Magnaghi, it is important to emphasize the educational potential of the discipline, the main purpose of which is to provide tools that are useful for knowing, presenting, caring for and managing a territory. [8]

\section{DATA \& METHODS}

In connection with the above, the present study examines the educational potential of geography by exploring the possibilities for the transformation of geographical knowledge into competence. A similar approach has been used by contemporary Italian didactics of geography (2017). [11]

In recent years, the ongoing dialogue between the research of scientists in the field and teaching in high school has led to tangible progress from an epistemological point of view, which strengthens both. [5] De Vecchis also speaks of the appropriate requirement "to integrate classical tools for modern research", which do not aim to describe the world, but to instill "great basic ideas that no longer want to present only concepts". The author in his work aims to suggest teaching through a research approach. [4]

The relationship between research and school teaching increasingly encourages the orientation towards planning through skills or "a set of components that combine to form competence: not only what the student knows, but also what he can do with what he knows". [3] The main idea of this relationship is to improve the effectiveness of geography education in high school, as well as to realize and understand the complexity of human and natural processes that occur on our planet. [12]

According to scientists in the field, this dialogue is extremely fruitful and will lead to a significant improvement in the social role of geographical science. In our attempt to prove that the discipline in question is not only an encyclopedic reference book, there is a risk of ignoring the fact that it contains fundamental knowledge and prerequisites for a wider response. We must also be careful in teaching, because sometimes the fundamental importance of localization competence is lost sight of. This is essential, according to Giorda, who argues that "it should be formulated not as an ability in itself [...], but when applied in a real context, to provide explanations and interpret, for example, potential and limits in a given territory in relation to its geographical location." [7]

The transition from the concept of the question of locating objects, understood from the point of view of knowledge, to the one that understood from the point of view of competence is crucial, as it returns the need to know the facts without questioning the educational value of geographical science.

Central to this transition is the cessation of geoelements to be objects. They become places, each of which has its own specific meaning and potential. In this way, the localization of an object in a specific place and the understanding of its functionality in a given territory can be used as a link between man and nature. This, according to researchers, could motivate and increase students' interest in geography. It is necessary for children to give real value to the knowledge of localization, to put it in context and to problematize it in order to give it meaning. Here the role of the teacher is to stimulate this ability by encouraging the student to constantly enrich their knowledge on the issue. Competence in locating geographical features can be activated in ways that stimulate 
research interest. They can be emotional, sensory or intellectual. Their number could be unlimited, due to the huge availability of working materials from various scientific sources, as well as the imagination of the teacher. His creativity should be aimed at clearly emphasizing the connection of an object with a place.

Here we could easily incorporate an interdisciplinary approach to learning, linking geography to history. The connection between the two sciences dates back to antiquity, and is especially relevant today. History, like geography, deals with the study of time and space. Valega's point of view on this issue is interesting in that he considers the visions of the concepts of "time" and "space" side by side, while noting that they oppose each other in the modern world. They offer, on the one hand, "the vision of modernity, according to which place exists independently of the subject and time is a property of place." And, on the other hand, "according to which place is in the subject and time lives in place." [10] In these statements we can see how the competence introduced by the school regulations presents great theoretical and practical tricks.

In this context, an in-depth didactic study could be proposed, aimed at creating a teaching unit that aims to use the potential of history as a useful discipline for geography. It is good to include teaching through skills that improve students' localization competence.

\section{DISSCUSION}

Modern research on teaching is increasingly proving that traditional frontal teaching is not effective in modern society. The problems come largely from the generational gap (teacher-student) and outdated teaching methods used by some teachers. The need to update them is inevitable. The main goal is to avoid the concept of teaching, which focuses only on the transfer of knowledge. It is necessary to look for new methods and approaches in education that present science in a clear and understandable language for children. New approaches should aim at acquiring or strengthening transversal and disciplinary skills. In this way the children will be motivated and the time in the classroom will be useful and fruitful.

Some of the suggestions made by teachers and researchers seeking to find effective and workable strategies for modernizing geography education include working with digital technologies. STEAM training is extremely relevant at the moment in the world and in Bulgaria. The Ministry of Education and Science supports and stimulates this relatively new method of teaching for the country, and in the coming years it is planned to equip STEAM space in every school in Bulgaria.

Geographic information systems (GIS) are also increasingly used in classrooms. Their skillful use could strengthen the links between different disciplines, such as history and geography. Thanks to interactive cartography, children can more easily acquire a landmark in space and comprehend the meaning and problems of a given territory.

The "inverted classroom" could also find a place in modern education. According to Ferri, this is "a system that, thanks to the use of educational technology, reverses the traditional teaching scheme and the resulting teacher-student relationship." [6] With this modernized approach to teaching, the classroom "is no longer the place to convey concepts, but is transformed into a space for work and discussion, where you learn to use knowledge through discussions with peers and the teacher." [6] The classroom should become "the place where one works according to the method of joint problem solving." [6]. During this time, the teacher should guide the class or group to discuss various issues, engaging in laboratory-type activities (including STEAM training) that "lies" on the practice of experiential learning. The focus in modern education should be on children. The teacher 
must guide, support and encourage the children's activities. It should give ideas, as well as actively involve each student in educational practice.

Thanks to this approach, the ability to use the new knowledge acquired during the lesson independently is strengthened. (see Tab. 1)

Table 1. Stages of learning in the inverted classroom, [13]

\begin{tabular}{|l|l|l|}
\hline Stage 1 & $\begin{array}{l}\text { Remembering } \\
\text { At home }\end{array}$ & $\begin{array}{l}\text { Recognition and memorization of facts } \\
\text { Understanding what the facts mean }\end{array}$ \\
\hline Stage 2 & Application & Application of rules, concepts, ideas \\
At school & Analysis & Breaking the information into pieces \\
& Evaluation & Clash to express the value of information and ideas \\
& Creating & Producing something beautiful and interesting \\
\hline
\end{tabular}

\section{CONCLUSION}

The modern world offers new and diverse opportunities, thanks to which the geographical science and teaching geography is developing. In this regard, the role of the teachers is key. They must work to form the knowledge, skills and competencies of students. The formed competence will allow the students not only to locate points in the geospace, but to attach importance to the place, to turn it into an emotional or intellectual experience.

\section{REFERENCES}

[1] Василева, М., Актуални въпроси на съвременната дидактика на географията, МЕЛАНИ, ISBN 978-954-92917-9-7, София, 2018а

[2] Василева, М., Методика на обучението по география - едно по-широко разбиране за методите на обучение, УИ "Св. Климент Охридски", ISBN 978-954-07-4355-4, София, 20186.

[3] Castoldi M. (2011), Progettare per competenze, Carocci, Roma.

[4] De Vecchis G. (2006), Didattica della geografia, Utet-DeAgostini, Novara.

[5] De Vecchis G. (2016), Insegnare geografia. Teoria, metodi e pratiche, Utet-DeAgostini, Novara.

[6] Ferri P. (2013), La scuola 2.0. Verso una didattica aumentata dalle tecnologie, Spaggiari, Parma.

[7] Giorda C. (2014), Il mio spazio nel mondo. Geografia per la scuola dell'infanzia e primaria, Carocci, Roma.

[8] Magnaghi A. (2011), "Educare al territorio: conoscere, rappresentare, curare, governare, in Giorda C. e Puttilli M., a cura di, Educare al territorio, educare il territorio.

Geografia per la formazione, Carocci, Roma, pp. 32-42.

[9] Vallega A. (2004), Le grammatiche della geografia, Pàtron, Bologna.

[10] Vallega A. (2006), La geografia del tempo. Saggio di geografia culturale, Utet, NovaraTorino.

[11] M. Vasileva, The map - "evergreen" in geography education, Journal of the Bulgarian Geographical Society , vol:41, 2019, p. 94-100

[12] Wasileva, M., Naydenov, K., Atanasov, D., CONTEMPORARY TRENDS IN GEOGRAPHICAL EDUCATION, InterCarto/InterGIS, редактор/и:Vladimir S. Tikunov , издателство:ELIBRARY.RU , 2017, стр.:205-210, doi:http://dx.doi.org/10.24057/2414-91792017-3-23-205-210, Ref

[13] https://flipnet.it/disponibili-nuovi-fondi-per-la-formazione-20-21/ 